\title{
Cardiovascular dysfunction in obesity and new diagnostic imaging techniques: the role of noninvasive image methods
}

This article was published in the following Dove Press journal:

Vascular Health and Risk Management

10 May 20II

Number of times this article has been viewed

José Augusto A Barbosa'

Alexandre B Rodrigues'

Cleonice Carvalho C Mota'

Márcia M Barbosa ${ }^{2}$

Ana C Simões e Silva'

'Department of Pediatrics, Faculty of Medicine, Federal University of Minas Gerais (UFMG), Belo Horizonte, Minas Gerais, Brazil; ${ }^{2}$ Ecocenter, Socor Hospital, Belo Horizonte, Minas Gerais, Brazil
Correspondence: José Augusto A Barbosa Estrada para Nova Lima, 345, Apto 703, Belvedere, Belo Horizonte, Minas Gerais, Brazil

$\mathrm{Tel}+553191844141$

Fax +55 2I 32288100

Email jalmeidabarbosa@uol.com.br

\begin{abstract}
Obesity is a major public health problem affecting adults and children in both developed and developing countries. This condition often leads to metabolic syndrome, which increases the risk of cardiovascular disease. A large number of studies have been carried out to understand the pathogenesis of cardiovascular dysfunction in obese patients. Endothelial dysfunction plays a key role in the progression of atherosclerosis and the development of coronary artery disease, hypertension and congestive heart failure. Noninvasive methods in the field of cardiovascular imaging, such as measuring intima-media thickness, flow-mediated dilatation, tissue Doppler, and strain, and strain rate, constitute new tools for the early detection of cardiac and vascular dysfunction. These techniques will certainly enable a better evaluation of initial cardiovascular injury and allow the correct, timely management of obese patients. The present review summarizes the main aspects of cardiovascular dysfunction in obesity and discusses the application of recent noninvasive imaging methods for the early detection of cardiovascular alterations.
\end{abstract}

Keywords: cardiovascular risk, endothelium dysfunction, obesity, strain and strain rate, tissue Doppler

\section{Introduction}

The prevalence of overweight and obesity is increasing at a very high rate, affecting an estimated 300 million individuals worldwide. A number of studies carried out in developing countries report an approximate $20 \%$ prevalence of obesity. ${ }^{1-3}$ The prevalence is even higher in developed countries. In 2007-2008, obesity in the United States was reported to affect $32.21 \%$ of male adults and $35.5 \%$ of female adults. ${ }^{4,5}$ Considering the standard definition for overweight and obesity in the pediatric population ( 2 to 19 years of age), $11.9 \%$ were at or above the 97 th percentile of the body mass index (BMI), 16.9\% were at or above the 95th percentile and $31.7 \%$ were at or above the 85 th percentile. ${ }^{6-8}$ Childhood obesity increases the risk of obesity in adulthood tenfold and pediatric patients that persistently remain at the 99th BMI percentile are at very high risk for severe adult obesity. ${ }^{9,10}$

Obesity is commonly associated with a combination of comorbidities, which collectively comprise metabolic syndrome. In 1998, the World Health Organization published a definition for metabolic syndrome that includes insulin resistance, raised plasma triglycerides, low high-density lipoprotein, central obesity or a BMI greater than $30 \mathrm{~kg} / \mathrm{m}^{2}$ for adults and above the 95 th percentile for children and adolescents, microalbuminuria ( $>20 \mu \mathrm{g} / \mathrm{min}$ ) or elevated albumin-to-creatinine ratio $(\geq 30 \mathrm{mg} / \mathrm{g})$ and hypertension. ${ }^{11,12}$ Recently, a number of other clinical and laboratorial features 
have been associated with metabolic syndrome, such as nonalcoholic fatty liver disease, polycystic ovarian syndrome, atherosclerosis, proinflammatory state and oxidative stress. Moreover, body measurements, such as the waist-to-hip ratio and waist circumference, seem to predict the risk of mortality better than the BMI. ${ }^{12,13}$

Cardiovascular complications associated with obesity contribute to high rates of morbidity and mortality. Hypertension is three to five times more common in obese subjects in comparison to individuals within the ideal weight range. ${ }^{14}$ All components of metabolic syndrome are independent predictors of cardiovascular events, such as stroke, cardiomyopathy, coronary artery disease, myocardial infarction, congestive heart failure and sudden cardiac death. ${ }^{15}$ Central (mesenteric and omental) obesity is highly correlated to the risk of cardiovascular disease. ${ }^{16-18}$ The risk of death among obese individuals (BMI $>30 \mathrm{~kg} / \mathrm{m}^{2}$ ) is two to three times higher than nonobese individuals and the severely obese individuals (BMI $>35 \mathrm{~kg} / \mathrm{m}^{2}$ ) have a 5-to-20-year decrease in life expectancy in comparison to nonobese individuals matched for age and gender. ${ }^{14,16}$

The present review summarizes the main aspects of cardiovascular dysfunction in obesity and discusses the application of recent noninvasive imaging methods in this context.

\section{Endothelial dysfunction in obesity}

Endothelial dysfunction is associated with a large number of clinical conditions and laboratorial alterations, including diabetes mellitus, hypercholesterolemia, hypertension, insulin resistance, advanced age and obesity. ${ }^{19}$ Adipose tissue plays a key role in the development of endothelial dysfunction in obese patients. ${ }^{20}$ An increase in fat mass increases the size and number of adipocytes. Changes associated with adipocyte hypertrophy seem to produce cell dysfunction. An excessive amount of lipid stored in adipocytes leads to functional abnormalities of the endoplasmic reticulum and mitochondria, which, in turn, contribute to intracellular and systemic disorders such as the stimulation of a proinflammatory state, insulin resistance, and high production of free fatty acids (FFAs). ${ }^{21}$ FFAs accumulate in nonadipose tissue and cause an overproduction of metabolic toxins. Both effects impair insulin signaling and glucose tolerance. ${ }^{22}$ Nonalcoholic fatty liver disease also plays a very important role in this process. ${ }^{23}$

In addition, chronic subclinical inflammation associated with visceral and central adiposity often occurs in patients with metabolic syndrome. The major mediators responsible for the balance between proinflammatory and anti-inflammatory pathways are C-reactive protein (CRP), leptin, tumor necrosis factor $\alpha$ (TNF- $\alpha)$, interleukin-6 (IL-6), serum retinol-binding protein 4 (sRBP-4), plasminogen activator inhibitor 1 (PAI-1), nitric oxide (NO), and adiponectin. ${ }^{21,24-27}$ Fat in the liver also represents a site beyond adipose tissue that independently contributes to the synthesis of inflammatory mediators such as CRP, IL-6 and PAI-1, which are increased in nonalcoholic fatty liver disease. ${ }^{23,28}$ The predominance of inflammatory mediators in obese patients also contributes to endothelial dysfunction.

CRP is predominantly produced by the liver in response to IL-6 and is chronically elevated in metabolic syndrome. CRP levels are positively correlated with BMI and visceral fat accumulation. ${ }^{29} \mathrm{CRP}$ inhibits the formation of $\mathrm{NO}$ by endothelial cells. The lack of NO promotes vasoconstriction, leukocyte adherence, platelet activation, oxidation, and thrombosis, thereby leading to endothelial dysfunction and arterial hypertension. ${ }^{21,24}$ High levels of CRP are also predictive of atherothrombotic events. ${ }^{26}$

Leptin is secreted by adipose tissue. This secretion is directly proportional to adipose tissue mass. Leptin receptors are mainly expressed in the hypothalamus and brainstem neuronal circuit and control satiety, energy expenditure, and neuroendocrine functions. Obese patients have elevated levels of endogenous leptin that fail to suppress appetite, thus characterizing a leptin-resistant state. High levels of leptin have been linked to vasculopathy via obesity associated with hypertension. ${ }^{20,25,30}$ High leptin levels are also associated with insulin resistance and correlated with artherosclerosis and coronary artery calcifications..$^{31,32}$

TNF- $\alpha$ is a proinflammatory cytokine whose expression is elevated in obese adipose tissue. This cytokine is mainly produced from macrophages within the adipose tissue as well as adipocytes themselves. ${ }^{21,33}$ There is a strong relationship between TNF- $\alpha$ and the effect of the lipoprotein lipase, which is responsible for the breakdown of circulating triglycerides and very-low-density cholesterol. In metabolic syndrome, there is an increase in macrophage TNF- $\alpha$ expression and a decrease in the effect of lipoprotein lipase, thereby causing hypertriglyceridemia. TNF- $\alpha$ impairs insulin signaling by an increase in circulating FFAs, which induces insulin resistance. TNF- $\alpha$ also plays a role in stimulating the expression of other inflammatory mediators, such as IL-6, and reduces the expression of anti-inflammatory mediators, such as adiponectin. ${ }^{20,25}$ Furthermore, TNF- $\alpha$ induces insulin resistance through the downregulation of the tyrosine kinase activity of insulin receptors and the serine phosphorylation 
of insulin substrate 1, which converts this protein into an insulin-receptor inhibitor in adipose tissue. ${ }^{34} \mathrm{TNF}-\alpha$ also activates transcription nuclear factor kappa beta $(\mathrm{NF}-\kappa \beta)$, which induces inflammatory changes within the vessel wall. ${ }^{35,36}$ TNF- $\alpha$ is a proinflammatory cytokine that plays a very important role in vascular dysfunction in obese patients.

sRBP-4 is a circulating protein of the lipocalin family associated with visceral adiposity and insulin resistance. sRBP-4 is secreted by the liver and adipocytes, reaching high concentrations in chronic low-state inflammation. ${ }^{35}$ In mouse models, sRB4 induces insulin resistance in the liver and skeletal muscle. ${ }^{35}$ In humans, a number of studies report an association between sRB4, insulin resistance, and type 2 diabetes. $^{21}$

PAI-1 is a member of the serine protease inhibitor family and is the primary inhibitor of fibrinolysis. It is secreted mainly by platelets and vascular endothelium and is also produced by adipocyte cells. Plasma PAI-1 is elevated in individuals with obesity and plays a key role in promoting thrombus formation following the rupture of atherosclerotic plaque. ${ }^{25,37}$

NO has a large number of antiatherogenesis actions, including induction of potent vasodilatation, capacity to diminish the adhesion of monocytes and the aggregation of platelets to the endothelium, and has an inhibitory effect on the proliferation of smooth muscle cells. ${ }^{38}$ Reduced synthesis of $\mathrm{NO}$ is also an early inducer of obesity. Insulin resistance and the chronic rise in plasma glucose enhance the expression of glutamine fructose 6 phosphate transaminase, which in turn stimulates the production of glucosamine, thereby favoring oxidative stress in endothelial cells. ${ }^{39,40}$ TNF- $\alpha$ also plays a role in this process as it inhibits endothelium-dependent vasorelaxation by increasing the generation of reactive oxygen species, which activate $\mathrm{NF}-\kappa \beta$, a transcription regulator of molecular adhesion important to the control of inflammatory and oxidative states of vascular endothelial cells. ${ }^{19,41-43}$

Adiponectin is a protein with 247 amino acids produced by adipocytes (adipokine) that exerts potent endotheliumprotective effects. ${ }^{44}$ Adiponectin levels are significantly lower in obese individuals in comparison to nonobese individuals and have been negatively correlated with percentage of body fat, waist-to-hip ratio and abdominal fat. ${ }^{45}$ Serum adiponectin circulates in three forms: low-, middle-, and high-molecular weight, which is the most active form. Adiponectin receptors are expressed in muscle, liver, and fat cells. ${ }^{46}$ Low concentrations of adiponectin contribute to a variety of obesityrelated diseases, including diabetes, vascular abnormalities, and heart disease, and are inversely associated with CRP and TNF- $\alpha$ levels. ${ }^{45,46}$ The main effects of adiponectin are the regulation of glucose metabolism, the improvement of sensitivity to insulin, the reduction in atherosclerotic lesions, the inhibition of monocyte adhesion to endothelial cells, the suppression of macrophage transformation into foam cells, and the decrease in the proliferation and migration of smooth muscle cells. ${ }^{35}$ It also increases endothelial NO production, thereby enhancing vasodilatation and inhibiting platelet aggregation. Adiponectin influences cardiac remodeling by suppressing pathological heart growth and is believed to have a protective effect on ischemic/reperfusion cardiac injury. $^{22,44,45,47-49}$ Nonalcoholic fatty liver disease has been also associated to low serum levels of adiponectin. ${ }^{23}$

\section{Atherosclerosis and coronary artery disease in obesity}

Obesity is an independent predictor of coronary artery disease. Among men aged under 50 years, obese individuals have twice the risk of coronary disease and obese women of a similar age have a 2.4 -fold greater risk..$^{50}$

Obesity results in increased deposition of perivascular fat around the heart and its major branches. This increased adipose tissue surrounding the blood vessels causes the overproduction of proinflammatory and profibrotic cytokines, leading to inflammation and atherosclerosis, with a consequent increase in intima-media thickness and decrease in arterial distensibility. ${ }^{17}$ The activation of the renninangiotensin-aldosterone system and of the sympathetic nervous system in metabolic syndrome leads to an increase in coronary vasoconstriction, which significantly contributes to the imbalance between coronary blood flow and myocardial metabolism. ${ }^{15}$ Experimental studies have demonstrated that, even in the early stage of obesity, there is a reduction in coronary endothelium-dependent vasorelaxation. ${ }^{51}$

Acute coronary syndromes are usually triggered by the rupture or erosion of atheromatous plaque; when the plaque ruptures, endothelial tissue factor is exposed to the blood and activates the coagulation cascade, causing thrombus formation..$^{29}$

\section{Arterial hypertension in obesity}

The prevalence of hypertension in obese patients in the United States is on the rise and individuals with a BMI greater than 40 have a sevenfold greater likelihood of being hypertensive. ${ }^{52}$ Obesity in children and adolescents also leads to hypertension. Chiolero and colleagues conducted a prevalence study on hypertension and found that this condition was attributed to overweight or obesity in 37\% of cases. ${ }^{53}$ In Switzerland, Maggio and colleagues found an 
association between obese children and systolic hypertension in $47.6 \%$ of patients as well as an increase in left ventricular mass partially caused by high systemic blood pressure. ${ }^{54}$ Obese children have a tenfold greater risk of developing hypertension as young adults than nonobese children and a continuous relationship between BMI and arterial pressure has been reported. ${ }^{7,55}$ One study reports that $10 \mathrm{~kg}$ of excess body weight is associated with a $3.0-\mathrm{mmHg}$ higher systolic and $2.3-\mathrm{mmHg}$ higher diastolic blood pressure. ${ }^{56}$ Stabouli and colleagues ${ }^{57}$ reported that obese adolescents have higher blood pressure and greater carotid artery intima-media thickness in comparison to nonobese pairs.

The mechanism of hypertension in metabolic syndrome is highly complex. The obese-related inflammatory state is one of the factors probably responsible for hypertension. ${ }^{58}$ The inflammatory state leads to hyperinsulinemia, insulin resistance, dyslipidemia, and oxidative stress, along with serious damage to organ systems. Obese patients have increased systemic blood volume. The normal compensatory response to an elevated cardiac output, which should be a drop in peripheral vascular resistance, is hindered in obese patients with hypertension, exhibiting an inappropriately normal total peripheral resistance. ${ }^{59}$ Studies have shown that increased sympathetic activity and hypoactivity of the parasympathetic nervous system, even in children, also results in an increased incidence of hypertension by augmenting sodium retention and vascular smooth muscle hypertrophy, affecting glucose delivery to the muscles and postprandial lipid clearance. ${ }^{60-62}$ The increasing of the FFAs, along with increased levels of circulating glucose, promotes insulin secretion by the pancreas, resulting in hyperinsulinemia. These events, in turn, can cause increased sodium reabsorption and sympathetic nervous system activity, with subsequent development or worsening of hypertension. ${ }^{18}$

The activation of the rennin-angiotensin-aldosterone system also significantly contributes to hypertension in obese patients. ${ }^{35,60}$ Adipose tissue is able to synthesize the components of the rennin-angiotensin-aldosterone system. ${ }^{35,60}$ In this regard, the formation of angiotensin II in the adipose tissue enhances the production of proinflammatory and profibrotic cytokines $^{35,50}$ and stimulates per se vasoconstriction, smooth muscle vascular cell proliferation, and endothelial dysfunction. ${ }^{58}$ Beside angiotensin II, the elevation of plasma levels of aldosterone might promote myocardial tissue growth. ${ }^{60}$

\section{Left ventricular involvement in obesity}

Cardiac involvement in obesity has been frequently reported in the literature, and the most frequently found abnormalities are: increased left ventricular diameters and mass, eccentric hypertrophy, diastolic dysfunction and, occasionally, systolic dysfunction and heart failure. ${ }^{63-65}$ Indeed, obesity has been linked to a spectrum of minor cardiovascular abnormalities, ranging from a hyperdynamic circulation to subclinical structural changes.

\section{Congestive heart failure in obesity}

Excess weight has been linked to heart failure and mortality. For each increment of one above 30 on the BMI, the risk of developing heart failure increases $5 \%$ in men and $7 \%$ in women. ${ }^{50}$ Obesity has been associated with systolic and diastolic heart dysfunction. In a cross-sectional study, Ammar and colleagues found a strong correlation between left ventricular systolic and diastolic dysfunction and central obesity, as measured by the waist-to-hip ratio. ${ }^{66}$

Studies have documented a better chance of survival from cardiac events in patients with decreased left ventricular ejection fraction and a higher BMI in comparison to those with a lower BMI, which is known as the "obesity paradox". The pathophysiology of the obesity paradox is unknown and some authors state that this paradox could be explained by an additional disease in patients with low BMI, such as lung disease.$^{67}$ Kapoor and Heidenreich have recently reported that the mortality rate in cardiac events is increased in obese patients with a BMI of 45 or more in comparison to lean peers. ${ }^{68}$ Moreover, among a cohort of 1,790 patients, Frankenstein and colleagues found that the obesity paradox in patients with stable heart failure did not persist after matching for clinical characteristics and disease severity. ${ }^{69}$

There are studies confirming the relationship between left atrial size and the development of adverse cardiovascular outcomes and those describing a strong correlation between BMI and atrial fibrillation, which deteriorates the cardiac failure. $^{70,71}$

\section{The role of noninvasive image methods in obesity}

Metabolic syndrome and its association with vascular and cardiac dysfunction is currently the greatest cause of mortality and this situation is expected to continue in the future. ${ }^{72}$ Noninvasive techniques for evaluating vascular dysfunction such as flow-mediated dilatation, pulse wave velocity, carotid intima-media thickness, and transient elastography to evaluate fatty liver disease ${ }^{73}$ are very good surrogate vascular markers. For the early assessment of cardiac dysfunction, tissue Doppler, strain, and strain rate have proven useful in patients with obesity and other morbidities. 
Endothelial dysfunction with a reduction in the bioavailability of endothelium-derived nitric oxide is an early event in atherosclerotic change. Flow-mediated inflammation is a good way to assess subclinical vascular disease and is significantly correlated with invasive tests. Its use with a combination of other exams, such as carotid intima-media thickness and pulse wave velocity, is of very strong clinical importance to the determination of clinical or subclinical atherosclerosis. ${ }^{7-76}$ However, Biasucci and colleagues have found that vascular function was paradoxically better among severely obese than in nonseverely obese patients and suggested that this group of patients might be partially protected from atherosclerosis probably by a greater mobilization of endothelial progenitor cells. ${ }^{77}$

In the young population, studies have shown that obesity is associated with increased arterial wall stiffness, as determined by carotid intima-media thickness. ${ }^{78,79}$ Diminished flow-mediated dilation has been observed in other pathologies, such as Kawasaki disease and type 1 diabetes mellitus, but there is yet no direct relationship between obesity and altered flow-mediated dilation. ${ }^{80,81}$ Further studies are needed, but these are very promising markers for the early assessment of cardiovascular disease, even in young patients.

Transient elastography is a noninvasive method for detection of cirrhosis in patients with chronic liver disease by measuring the liver stiffness. It is a new method to evaluate liver disease instead of biopsy, which is invasive and with potential life-threatening complications. It should also be pointed out that liver stiffness evaluation by using transient elastography measurements can be technically difficult in obese patients. ${ }^{82,83}$

Standard and new echocardiography techniques for the determination of coronary flow and early changes in systolic and diastolic left ventricle function are very important tools for assessing obese patients, even in the child population. Transthoracic Doppler echocardiography assessment of coronary flow velocity is an established noninvasive and clinically useful method to provide physiological information on the coronary circulation in obese patients. ${ }^{84} \mathrm{New}$ echocardiography techniques, such as tissue Doppler imaging, strain, and strain rate, are useful tools for assessing cardiac dysfunction in adults and children. These techniques permit a quantitative assessment of both global and regional function and timing of myocardial events as well as the assessment of early changes in systolic and diastolic function. ${ }^{85-87}$

Strain and strain rate assess function in heart segments. ${ }^{88}$ Strain is directly related to fiber shortening and strain rate is the speed of fiber shortening, which is a measure of contractility ${ }^{89}$ The longitudinal, radial, and circumferential function can be measured by tissue Doppler myocardial imaging and the B-mode imaging using the Speckle tracking technique ${ }^{89}$ These methods are important to assessing subclinical myocardial dysfunction in a wide variety of diseases and the application of strain analysis has been implemented in numerous experimental and clinical studies for the investigation of cardiac function. ${ }^{89}$

Early detection of cardiovascular abnormalities is very important because the control of this process seems to be more effective during the initial stages of the disease. The potential impact of obesity on biventricular function has not been fully established. Since traditional echocardiographic measurements of ventricular function, such as ejection fraction and mitral inflow for the evaluation of the diastolic function are load-dependent, ${ }^{90,91}$ the investigation of right and left ventricle subclinical dysfunction in obesity by sensitive newer echocardiographic techniques, such as tissue Doppler imaging, myocardial strain and strain rate looks like very promising.

Tissue Doppler imaging, strain, and strain rate have been introduced to better quantify segmental and global dysfunction, with studies showing clinically silent incipient dysfunction in obesity detected by strain and strain rate. Wong and colleagues used strain and strain rate to study myocardial function and found that overweight subjects have reduced systolic and diastolic function, even after adjustments for mean arterial pressure, age, gender, and left ventricular mass. ${ }^{92}$ In 2006, the same authors used the same techniques to demonstrate the existence of right ventricular dysfunction in obese patients..$^{93}$ Gong and colleagues studied 200 patients with metabolic syndrome using strain and strain rate to evaluate cardiac function in comparison to lean controls and demonstrated left ventricular systolic and diastolic dysfunction in the obese group. In the study, multiple regression analysis revealed that the waist-to-hip ratio was an independent predictor of systolic dysfunction and that the waist-to-hip ratio and high-density lipoproteins cholesterol were independent predictors of diastolic dysfunction. ${ }^{94}$ Mehta and colleagues used tissue Doppler and found a decrease in diastolic function in obese children. ${ }^{95}$ In a prospective study involving healthy and obese individuals aged between 10 to 18 years, Lorch and Sharkey found a decrease in systolic strain in the obese group in comparison to the lean group. ${ }^{96}$ More recently, Ingul and colleagues have reported an improvement in cardiac function, as evaluated by strain and strain rate, in obese adolescents after a training program. ${ }^{97}$

The left atrium is important in all phases of the cardiac cycle. During ventricular systole and isovolumic relaxation, 
Table I Recent studies using tissue Doppler, strain, and strain rate to evaluate cardiac function in obese subjects

\begin{tabular}{|c|c|c|c|c|}
\hline $\begin{array}{l}\text { Author and } \\
\text { year }\end{array}$ & Study population & $\begin{array}{l}\text { Cutoffs of BMI }\left(\mathrm{kg} / \mathrm{m}^{2}\right) \\
\text { or waist circumference }(\mathrm{cm})\end{array}$ & Results & Commentary \\
\hline Metha et $\mathrm{al}^{95}$ & $\begin{array}{l}\text { Obese children }(n=25) \\
\text { Control: } 13.8 \pm 1.9 \text { years } \\
\text { Obese: } 14.4 \pm 2.1 \text { years }\end{array}$ & BMI $>25$ (independent of age) & $\begin{array}{l}\text { Decrease in diastolic } \\
\text { function }\end{array}$ & $\begin{array}{l}\text { Healthy obese children with } \\
\text { no comorbidities }\end{array}$ \\
\hline Wong et $\mathrm{al}^{92}$ & $\begin{array}{l}\text { Obese adults }(n=109) \\
\text { Control: } 46 \pm 10 \text { years } \\
\text { Overweight: } 45 \pm 11 \text { years } \\
\text { Mild obesity: } 42 \pm 8 \text { years } \\
\text { Severe obesity: } 43 \pm 10 \text { years }\end{array}$ & $\begin{array}{l}\text { Groups } \\
\text { I-BMI: } 25-29.9 \text { overweight } \\
\text { 2-BMI: } 30-34.9 \text { mild obesity } \\
\text { 3-BMI }>35 \text { severe obesity }\end{array}$ & $\begin{array}{l}\text { Left ventricular systolic } \\
\text { and diastolic dysfunction } \\
\text { in patients with moderate } \\
\text { to severe obesity }\end{array}$ & $\begin{array}{l}\text { Insulin levels were a } \\
\text { significant predictor of } \\
\text { systolic and diastolic heart } \\
\text { dysfunction }\end{array}$ \\
\hline Di Salvo et al ${ }^{105}$ & $\begin{array}{l}\text { Obese children }(\mathrm{n}=150) \\
\text { Control: } 12 \pm 3 \text { years } \\
\text { Obese: } 12 \pm 3 \text { years }\end{array}$ & $\begin{array}{l}\text { Percentile }>97 \text { th for sex and } \\
\text { age (according to } C D C \text { ) }\end{array}$ & $\begin{array}{l}\text { Systolic dysfunction in } \\
\text { both right and left } \\
\text { ventricle }\end{array}$ & $\begin{array}{l}\text { Healthy obese children with } \\
\text { no comorbidities }\end{array}$ \\
\hline Wong et $\mathrm{al}^{93}$ & $\begin{array}{l}\text { Obese adults }(\mathrm{n}=1 \mathrm{I} 2) \\
\text { Control: } 43 \pm 1 \mathrm{I} \text { years } \\
\text { Overweight: } 44 \pm 10 \text { years } \\
\text { Mild obesity: } 41 \pm 8 \text { years } \\
\text { Severe obesity: } 44 \pm 13 \text { years }\end{array}$ & $\begin{array}{l}\text { BMI: } 25-29.9 \text { overweight } \\
\text { BMI: } 30-34.9 \text { mild obesity } \\
\text { BMI: }>35 \text { severe obesity }\end{array}$ & $\begin{array}{l}\text { Increase in BMI associated } \\
\text { with increased severity of } \\
\text { right ventricle dysfunction }\end{array}$ & $\begin{array}{l}\text { BMI was associated with } \\
\text { right ventricular dysfunction, } \\
\text { regardless of sleep apnea }\end{array}$ \\
\hline $\begin{array}{l}\text { Lorch and } \\
\text { Sharkey }{ }^{96}\end{array}$ & $\begin{array}{l}\text { Obese children }(n=53) \\
\text { Control: } 13.9 \pm 2.3 \\
\text { Obese: } 13.8 \pm 2.4\end{array}$ & $\begin{array}{l}\text { Percentile }>95 \text { th for sex and } \\
\text { age }(C D C)^{*}\end{array}$ & $\begin{array}{l}\text { Systolic and diastolic } \\
\text { dysfunction of left } \\
\text { ventricle }\end{array}$ & Retrospective study \\
\hline Tumuklu et al ${ }^{106}$ & $\begin{array}{l}\text { Obese adults }(n=33) \\
\text { Control: } 43 \pm \text { II } \\
\text { Moderate obesity: } 42 \pm 6 \\
\text { Severe obesity: } 42 \pm 8\end{array}$ & $\begin{array}{l}\text { BMI: } 30-34.9 \text { moderate obesity } \\
\text { BMI: }>35 \text { severe obesity }\end{array}$ & $\begin{array}{l}\text { Systolic left ventricular } \\
\text { dysfunction }\end{array}$ & $\begin{array}{l}\text { Healthy obese subjects } \\
\text { with no comorbidities }\end{array}$ \\
\hline Di Salvo et al ${ }^{104}$ & $\begin{array}{l}\text { Obese children }(n=150) \\
\text { Control: } 12 \pm 3 \text { years } \\
\text { Obese: } 12 \pm 3 \text { years }\end{array}$ & $\begin{array}{l}\text { Percentile }>97 \text { th for sex and } \\
\text { age (according to CDC) }\end{array}$ & $\begin{array}{l}\text { Reduced left and right } \\
\text { atrial myocardial } \\
\text { deformation }\end{array}$ & $\begin{array}{l}\text { Healthy obese children } \\
\text { with no comorbidities }\end{array}$ \\
\hline Sürücü et al ${ }^{107}$ & $\begin{array}{l}\text { Obese adults }(n=25) \\
\text { Control: } 53 \pm 6 \text { years } \\
\text { Obese: } 54 \pm 8 \text { years }\end{array}$ & $\mathrm{BMI} \geq 27$ & $\begin{array}{l}\text { Right and left ventricular } \\
\text { systolic and diastolic } \\
\text { dysfunction }\end{array}$ & $\begin{array}{l}\text { Tissue Doppler technique } \\
\text { and all subjects of the study } \\
\text { with normal angiography }\end{array}$ \\
\hline Gong et $\mathrm{a}^{94}$ & $\begin{array}{l}\text { Obese adults }(n=200) \\
\text { Control: } 49 \pm 10 \text { years } \\
\text { Obese: } 50 \pm 9 \text { years }\end{array}$ & $\begin{array}{l}\text { Waist circumference } \geq 90 \mathrm{~cm} \\
\text { for men and } \geq 80 \mathrm{~cm} \text { for } \\
\text { women }\end{array}$ & $\begin{array}{l}\text { Left ventricular systolic } \\
\text { and diastolic dysfunction }\end{array}$ & $\begin{array}{l}\text { Obese patients with } \\
\text { comorbidities including } \\
\text { hypertension, dyslipidemia } \\
\text { and hyperglycemia }\end{array}$ \\
\hline Gulel et al ${ }^{103}$ & $\begin{array}{l}\text { Obese adults }(n=37) \\
\text { Control: } 35 \pm 5 \text { years } \\
\text { Obese: } 36 \pm 11 \text { years }\end{array}$ & $\mathrm{BMI} \geq 30 \mathrm{~kg} / \mathrm{m}^{2}$ & $\begin{array}{l}\text { No difference between } \\
\text { groups considering left } \\
\text { atrial function }\end{array}$ & No comorbidities \\
\hline Orhan et al ${ }^{108}$ & $\begin{array}{l}\text { Obese adults }(n=29) \\
\text { Control: } 47 \pm 7 \text { years } \\
\text { Obese: } 49 \pm 8 \text { years }\end{array}$ & $\mathrm{BMI} \geq 30 \mathrm{~kg} / \mathrm{m}^{2}$ & $\begin{array}{l}\text { Left and right ventricular } \\
\text { systolic and diastolic } \\
\text { dysfunction }\end{array}$ & No comorbidities \\
\hline
\end{tabular}

Abbreviations: BMI, body mass index; CDC, Centers for Disease Control and Prevention.

it serves as a reservoir that receives blood from the pulmonary venous return and stores energy in the form of pressure. During the early phase of ventricular diastole, the left atrium operates as a conduit for transferring blood into the left ventricle following the opening of the mitral valve due to a pressure gradient and through which blood flows passively from the pulmonary veins into the left ventricle; the contractile function of the left atrium, during the late phase of diastole, increases the left ventricular stroke volume by nearly $20 \% .^{71}$

Left atrial size is an expression of chronic left ventricular filling pressures. Early studies had demonstrated the value of left ventricular diameter in predicting prognosis of cardiac diseases and in the development of atrial fibrillation. More recently, left atrial volume has been shown to be an important and more accurate measurement of left atrial size and this measurement, indexed to body surface area, has been used to predict prognosis in several heart diseases. ${ }^{71,98,99}$ Although left atrial volume seems to correlate with diastolic filling pressures, accurate and direct measurements of the left atrial function have not been established.

Enlargement of the atria is associated with obesity and has been also linked with an increased risk of mortality. ${ }^{100}$ Using standard echocardiography techniques, Hirschler and 
colleagues concluded that left atrial enlargement is related to abdominal obesity and hypertension in children. ${ }^{101}$ Kosar and colleagues found that obese patients without cardiovascular disease exhibit enlargement of left atrium in standard echocardiography. ${ }^{102}$

Strain and strain rate methods have emerged as promising methods to evaluate atrial function, but with controversial results. Gulel and colleagues compared left atrial function using color tissue Doppler imaging in adults with a $\mathrm{BMI} \geq 30 \mathrm{~kg} / \mathrm{m}^{2}$ versus those with a BMI $<30 \mathrm{~kg} / \mathrm{m}^{2}$ and found no differences in systolic or diastolic atrial function between groups. ${ }^{103}$ On the other hand, Di Salvo and colleagues studied nonhypertensive children using strain and strain rate and found reduced left and right atrial function in the obese group. ${ }^{104}$ Further studies should be carried out to clarify these controversial results.

In summary, obesity, even without comorbidities, is generally associated with cardiac events. Overt systolic and diastolic dysfunction has been described in obesity. New findings, indicating the occurrence of pre-clinical systolic and diastolic dysfunction, even in young obese patients, suggest that obese patients should be carefully monitored in order to detect incipient dysfunction. Efforts should be made, not only to make obese patients lose weight and control other cardiovascular risk factors, but also to detect incipient atrial and ventricular dysfunction. If these patients should be treated before the development of overt ventricular dysfunction, remains to be established. Table 1 summarizes the most recent studies using tissue Doppler imaging, strain and strain rate to evaluate cardiac function in obese subjects.

\section{Disclosure}

The authors report no conflicts of interest in this work.

\section{References}

1. Misra A, Khurana L. Obesity and the metabolic syndrome in developing countries. J Clin Endocrinol Metab. Nov 2008;93(11 Suppl 1): S9-S30.

2. Abrantes M, Lamounier J, Colosimo E. Comparison of body mass index values proposed by Cole et al. (2000) and Must et al. (1991) for identifying obese children with weight-for-height index recommended by the World Health Organization. Public Health Nutr. May 2003;6(3): 307-311.

3. Marquezine G, Oliveira C, Pereira A, Krieger J, Mill J. Metabolic syndrome determinants in an urban population from Brazil: social class and gender-specific interaction. Int J Cardiol. Sep 2008;129(2):259-265.

4. Flegal K, Carroll M, Ogden C, Curtin L. Prevalence and trends in obesity among US adults, 1999-2008. JAMA. Jan 2010;303(3):235-241.

5. Cali A, Caprio S. Obesity in children and adolescents. J Clin Endocrinol Metab. Nov 2008;93(11 Suppl 1):S31-S36.

6. Cole T, Bellizzi M, Flegal K, Dietz W. Establishing a standard definition for child overweight and obesity worldwide: international survey. BMJ. May 2000;320(7244):1240-1243.
7. Jolliffe C, Janssen I. Vascular risks and management of obesity in children and adolescents. Vasc Health Risk Manag. 2006;2(2):171-187.

8. Ogden C, Carroll M, Curtin L, Lamb M, Flegal K. Prevalence of high body mass index in US children and adolescents, 2007-2008. JAMA. Jan 2010;303(3):242-249.

9. Thompson D, Obarzanek E, Franko D, et al. Childhood overweight and cardiovascular disease risk factors: the National Heart, Lung, and Blood Institute Growth and Health Study. J Pediatr. Jan 2007;150(1):18-25.

10. Freedman DS, Mei Z, Srinivasan SR, Berenson GS, Dietz WH. Cardiovascular risk factors and excess adiposity among overweight children and adolescents: the Bogalusa Heart Study. J Pediatr. Jan 2007;150(1):12-17, e12.

11. Reisin E, Alpert M. Definition of the metabolic syndrome: current proposals and controversies. Am J Med Sci. Dec 2005;330(6):269-272.

12. Reynolds K, He J. Epidemiology of the metabolic syndrome. Am J Med Sci. Dec 2005;330(6):273-279.

13. Haffner S. Abdominal adiposity and cardiometabolic risk: do we have all the answers? Am J Med. Sep 2007;120(9 Suppl 1):S10-S16; discussion S16-S17.

14. Cannon C. Obesity-related cardiometabolic complications. Clin Cornerstone. 2008;9(1):11-19; discussion 20-12.

15. Knudson J, Dincer U, Bratz I, Sturek M, Dick G, Tune J. Mechanisms of coronary dysfunction in obesity and insulin resistance. Microcirculation. 2007 Jun-Jul 2007;14(4-5):317-338.

16. Cannon C. Cardiovascular disease and modifiable cardiometabolic risk factors. Clin Cornerstone. 2008;9(2):24-38; discussion 39-41.

17. Gustafson B. Adipose tissue, inflammation and atherosclerosis. J Atheroscler Thromb. Apr 2010;17(4):332-341.

18. Aronne LJ, Nelinson DS, Lillo JL. Obesity as a disease state: a new paradigm for diagnosis and treatment. Clin Cornerstone. 2009;9(4):9-25; discussion 26-29.

19. Meyers M, Gokce N. Endothelial dysfunction in obesity: etiological role in atherosclerosis. Curr Opin Endocrinol Diabetes Obes. Oct 2007;14(5):365-369.

20. Hutley L, Prins J. Fat as an endocrine organ: relationship to the metabolic syndrome. Am J Med Sci. Dec 2005;330(6):280-289.

21. de Ferranti S, Mozaffarian D. The perfect storm: obesity, adipocyte dysfunction, and metabolic consequences. Clin Chem. Jun 2008;54(6):945-955.

22. Gill H, Mugo M, Whaley-Connell A, Stump C, Sowers J. The key role of insulin resistance in the cardiometabolic syndrome. Am J Med Sci. Dec 2005;330(6):290-294.

23. Lucero D, Zago V, Lopez GI, et al. Pro-inflammatory and atherogenic circulating factors in non-alcoholic fatty liver disease associated to metabolic syndrome. Clin Chim Acta. Jan 14, 2011;412(1-2): 143-147.

24. Sutherland J, McKinley B, Eckel R. The metabolic syndrome and inflammation. Metab Syndr Relat Disord. Jun 2004;2(2):82-104.

25. Kershaw E, Flier J. Adipose tissue as an endocrine organ. J Clin Endocrinol Metab. Jun 2004;89(6):2548-2556.

26. Cornier M, Dabelea D, Hernandez T, et al. The metabolic syndrome. Endocr Rev. Dec 2008;29(7):777-822.

27. Ong K, Wong L, Cheung B. The role of urotensin II in the metabolic syndrome. Peptides. May 2008;29(5):859-867.

28. Tarantino G, Savastano S, Colao A. Hepatic steatosis, low-grade chronic inflammation and hormone/growth factor/adipokine imbalance. World J Gastroenterol. Oct 14 2010;16(38):4773-4783.

29. Darvall K, Sam R, Silverman S, Bradbury A, Adam D. Obesity and thrombosis. Eur J Vasc Endovasc Surg. Feb 2007;33(2):223-233.

30. Soodini G. Adiponectin and leptin in relation to insulin sensitivity. Metab Syndr Relat Disord. Jun 2004;2(2):114-123.

31. Silha J, Krsek M, Skrha J, Sucharda P, Nyomba B, Murphy L. Plasma resistin, adiponectin and leptin levels in lean and obese subjects: correlations with insulin resistance. Eur J Endocrinol. Oct 2003;149(4): 331-335.

32. Beltowski J. Leptin and atherosclerosis. Atherosclerosis. Nov 2006;189(1):47-60. 
33. Trujillo M, Scherer P. Adipose tissue-derived factors: impact on health and disease. Endocr Rev. Dec 2006;27(7):762-778.

34. Aljada A. Endothelium, inflammation, and diabetes. Metab Syndr Relat Disord. Mar 2003;1(1):3-21.

35. Wassink A, Olijhoek J, Visseren F. The metabolic syndrome: metabolic changes with vascular consequences. Eur J Clin Invest. Jan 2007;37(1):8-17.

36. Kralisch S, Sommer G, Stangl V, et al. Secretory products from human adipocytes impair endothelial function via nuclear factor kappaB. Atherosclerosis. Feb 2008;196(2):523-531.

37. Bray G, Clearfield M, Fintel D, Nelinson D. Overweight and obesity: the pathogenesis of cardiometabolic risk. Clin Cornerstone. 2009;9(4):30-40; discussion 41-32.

38. Skilton M, Celermajer D. Endothelial dysfunction and arterial abnormalities in childhood obesity. Int $J$ Obes (Lond). Jul 2006;30(7):1041-1049.

39. Wu G, Meininger C. Nitric oxide and vascular insulin resistance. Biofactors. Jan-Feb 2009;35(1):21-27.

40. Kim F, Pham M, Maloney E, et al. Vascular inflammation, insulin resistance, and reduced nitric oxide production precede the onset of peripheral insulin resistance. Arterioscler Thromb Vasc Biol. Nov 2008;28(11):1982-1988.

41. Zhang C. The role of inflammatory cytokines in endothelial dysfunction. Basic Res Cardiol. Sep 2008;103(5):398-406.

42. Kralisch S, Sommer G, Deckert C, et al. Adipokines in diabetes and cardiovascular diseases. Minerva Endocrinol. Sep 2007; 32(3):161-171.

43. Pierce G, Lesniewski L, Lawson B, Beske S, Seals D. Nuclear factor$\{$ kappa\}B activation contributes to vascular endothelial dysfunction via oxidative stress in overweight/obese middle-aged and older humans. Circulation. Mar 2009;119(9):1284-1292.

44. Lihn A, Pedersen S, Richelsen B. Adiponectin: action, regulation and association to insulin sensitivity. Obes Rev. Feb 2005;6(1):13-21.

45. Hopkins T, Ouchi N, Shibata R, Walsh K. Adiponectin actions in the cardiovascular system. Cardiovasc Res. Apr 2007;74(1):11-18.

46. Sowers J. Endocrine functions of adipose tissue: focus on adiponectin. Clin Cornerstone. 2008;9(1):32-38; discussion 39-40.

47. Zhu W, Cheng K, Vanhoutte P, Lam K, Xu A. Vascular effects of adiponectin: molecular mechanisms and potential therapeutic intervention. Clin Sci (Lond). Mar 2008;114(5):361-374.

48. Do D, Alvarez J, Chiquette E, Chilton R. The good fat hormone: adiponectin and cardiovascular disease. Curr Atheroscler Rep. Mar 2006;8(2):94-99.

49. Lopaschuk G, Folmes C, Stanley W. Cardiac energy metabolism in obesity. Circ Res. Aug 2007;101(4):335-347.

50. Mathew B, Francis L, Kayalar A, Cone J. Obesity: effects on cardiovascular disease and its diagnosis. J Am Board Fam Med. 2008 Nov-Dec 2008;21(6):562-568.

51. Galili O, Versari D, Sattler K, et al. Early experimental obesity is associated with coronary endothelial dysfunction and oxidative stress. Am J Physiol Heart Circ Physiol. Feb 2007;292(2):H904-H911.

52. Good D, Morse S, Ventura H, Reisin E. Obesity, hypertension, and the heart. J Cardiometab Syndr. 2008;3(3):168-172.

53. Chiolero A, Cachat F, Burnier M, Paccaud F, Bovet P. Prevalence of hypertension in school children based on repeated measurements and association with overweight. J Hypertens. Nov 2007;25(11):2209-2217.

54. Maggio A, Aggoun Y, Marchand L, et al. Associations among obesity, blood pressure, and left ventricular mass. J Pediatr. Apr 2008;152(4):489-493.

55. Ippisch $\mathrm{H}$, Inge $\mathrm{T}$, Daniels $\mathrm{S}$, et al. Reversibility of cardiac abnormalities in morbidly obese adolescents. J Am Coll Cardiol. Apr 2008;51(14):1342-1348.

56. Poirier P, Giles T, Bray G, et al. Obesity and cardiovascular disease: pathophysiology, evaluation, and effect of weight loss. Arterioscler Thromb Vasc Biol. May 2006;26(5):968-976.

57. Stabouli S, Kotsis V, Papamichael C, Constantopoulos A, Zakopoulos N. Adolescent obesity is associated with high ambulatory blood pressure and increased carotid intimal-medial thickness. $J$ Pediatr. Nov 2005;147(5):651-656.
58. Hadi H, Carr C, Al Suwaidi J. Endothelial dysfunction: cardiovascular risk factors, therapy, and outcome. Vasc Health Risk Manag. 2005;1(3):183-198.

59. Reisin E, Jack A. Obesity and hypertension: mechanisms, cardio-renal consequences, and therapeutic approaches. Med Clin North Am. May 2009;93(3):733-751.

60. Morse S, Zhang R, Thakur V, Reisin E. Hypertension and the metabolic syndrome. Am J Med Sci. Dec 2005;330(6):303-310.

61. Sorof J, Poffenbarger T, Franco K, Bernard L, Portman R. Isolated systolic hypertension, obesity, and hyperkinetic hemodynamic states in children. J Pediatr. Jun 2002;140(6):660-666.

62. Yakinci C, Mungen B, Karabiber H, Tayfun M, Evereklioglu C. Autonomic nervous system functions in obese children. Brain Dev. May 2000;22(3):151-153.

63. Wong CY, O'Moore-Sullivan T, Leano R, Byrne N, Beller E, Marwick TH. Alterations of left ventricular myocardial characteristics associated with obesity. Circulation. Nov 9, 2004;110(19):3081-3087.

64. Urheim S, Edvardsen T, Torp H, Angelsen B, Smiseth OA. Myocardial strain by Doppler echocardiography. Validation of a new method to quantify regional myocardial function. Circulation. Sep 5, 2000; 102(10):1158-1164.

65. Greenberg NL, Firstenberg MS, Castro PL, et al. Doppler-derived myocardial systolic strain rate is a strong index of left ventricular contractility. Circulation. Jan 1, 2002;105(1):99-105.

66. Ammar K, Redfield M, Mahoney D, Johnson M, Jacobsen S, Rodeheffer R. Central obesity: association with left ventricular dysfunction and mortality in the community. Am Heart J. Nov 2008; 156(5):975-981.

67. Galal W, van Gestel Y, Hoeks S, et al. The obesity paradox in patients with peripheral arterial disease. Chest. Nov 2008;134(5):925-930.

68. Kapoor J, Heidenreich P. Obesity and survival in patients with heart failure and preserved systolic function: a U-shaped relationship. Am Heart J. Jan 2010;159(1):75-80.

69. Frankenstein L, Zugck C, Nelles M, Schellberg D, Katus HA, Remppis BA. The obesity paradox in stable chronic heart failure does not persist after matching for indicators of disease severity and confounders. Eur J Heart Fail. Dec 2009;11(12):1189-1194.

70. Tsang T, Barnes M, Miyasaka Y, et al. Obesity as a risk factor for the progression of paroxysmal to permanent atrial fibrillation: a longitudinal cohort study of 21 years. Eur Heart J. Sep 2008;29(18): 2227-2233.

71. Abhayaratna W, Seward J, Appleton C, et al. Left atrial size: physiologic determinants and clinical applications. J Am Coll Cardiol. Jun 2006;47(12):2357-2363.

72. Mathers C, Loncar D. Projections of global mortality and burden of disease from 2002 to 2030. PLoS Med. Nov 2006;3(11):e442.

73. Ahmad W, Ijaz B, Gull S, et al. A brief review on molecular, genetic and imaging techniques for HCV fibrosis evaluation. Virol J. 2011;8(1):53.

74. Raitakari OT, Celermajer DS. Flow-mediated dilatation. Br J Clin Pharmacol. Nov 2000;50(5):397-404.

75. Kobayashi K, Akishita M, Yu W, Hashimoto M, Ohni M, Toba K. Interrelationship between non-invasive measurements of atherosclerosis: flow-mediated dilation of brachial artery, carotid intima-media thickness and pulse wave velocity. Atherosclerosis. Mar 2004;173(1): $13-18$.

76. Stout M. Flow-mediated dilatation: a review of techniques and applications. Echocardiography. Aug 2009;26(7):832-841.

77. Biasucci LM, Graziani F, Rizzello V, et al. Paradoxical preservation of vascular function in severe obesity. Am J Med. Aug 2010;123(8):727-734.

78. Tounian P, Aggoun Y, Dubern B, et al. Presence of increased stiffness of the common carotid artery and endothelial dysfunction in severely obese children: a prospective study. Lancet. Oct 2001;358(9291):1400-1404.

79. Mimoun E, Aggoun Y, Pousset M, et al. Association of arterial stiffness and endothelial dysfunction with metabolic syndrome in obese children. J Pediatr. Jul 2008;153(1):65-70. 
80. Kadono T, Sugiyama H, Hoshiai M, et al. Endothelial function evaluated by flow-mediated dilatation in pediatric vascular disease. Pediatr Cardiol. Jul-Aug 2005;26(4):385-390.

81. McNeal C, Wilson D, Christou D, et al. The use of surrogate vascular markers in youth at risk for premature cardiovascular disease. J Pediatr Endocrinol Metab. Mar 2009;22(3):195-211.

82. Foucher J, Chanteloup E, Vergniol J, et al. Diagnosis of cirrhosis by transient elastography (FibroScan): a prospective study. Gut. Mar 2006;55(3):403-408.

83. Sebastiani G. Non-invasive assessment of liver fibrosis in chronic liver diseases: implementation in clinical practice and decisional algorithms. World J Gastroenterol. May 14, 2009;15(18):2190-2203.

84. Takeuchi M, Lodato JA, Furlong KT, Lang RM, Yoshikawa J. Feasibility of measuring coronary flow velocity and reserve in the left anterior descending coronary artery by transthoracic Doppler echocardiography in a relatively obese American population. Echocardiography. Mar 2005;22(3):225-232.

85. Yu C, Sanderson J, Marwick T, Oh J. Tissue Doppler imaging a new prognosticator for cardiovascular diseases. J Am Coll Cardiol. May 2007;49(19):1903-1914.

86. Kuznetsova T, Herbots L, Richart T, et al. Left ventricular strain and strain rate in a general population. Eur Heart J. Aug 2008;29(16):2014-2023.

87. Weidemann F, Eyskens B, Sutherland G. New ultrasound methods to quantify regional myocardial function in children with heart disease. Pediatr Cardiol. May-Jun 2002;23(3):292-306.

88. Heimdal A, Stoylen A, Torp H, Skjaerpe T. Real-time strain rate imaging of the left ventricle by ultrasound. J Am Soc Echocardiogr. Nov 1998;11(11):1013-1019.

89. Pavlopoulos H, Nihoyannopoulos P. Strain and strain rate deformation parameters: from tissue Doppler to 2D speckle tracking. Int J Cardiovasc Imaging. Jun 2008;24(5):479-491.

90. Lang RM, Bierig M, Devereux RB, et al. Recommendations for chamber quantification: a report from the American Society of Echocardiography's Guidelines and Standards Committee and the Chamber Quantification Writing Group, developed in conjunction with the European Association of Echocardiography, a branch of the European Society of Cardiology. $J$ Am Soc Echocardiogr. Dec 2005;18(12): 1440-1463.

91. Wang Y, Gutman JM, Heilbron D, Wahr D, Schiller NB. Atrial volume in a normal adult population by two-dimensional echocardiography. Chest. Oct 1984;86(4):595-601.

92. Wong C, O’Moore-Sullivan T, Leano R, Byrne N, Beller E, Marwick T. Alterations of left ventricular myocardial characteristics associated with obesity. Circulation. Nov 2004;110(19):3081-3087.

93. Wong C, O’Moore-Sullivan T, Leano R, Hukins C, Jenkins C, Marwick T. Association of subclinical right ventricular dysfunction with obesity. J Am Coll Cardiol. Feb 2006;47(3):611-616.

94. Gong H, Tan H, Fang N, et al. Impaired left ventricular systolic and diastolic function in patients with metabolic syndrome as assessed by strain and strain rate imaging. Diabetes Res Clin Pract. Mar 2009;83(3):300-307.
95. Mehta SK, Holliday C, Hayduk L, Wiersma L, Richards N, Younoszai A. Comparison of myocardial function in children with body mass indexes $\geq 25$ versus those $<25 \mathrm{~kg} / \mathrm{m}^{2}$. Am J Cardiol. Jun 15 2004;93(12):1567-1569.

96. Lorch S, Sharkey A. Myocardial velocity, strain, and strain rate abnormalities in healthy obese children. J Cardiometab Syndr. 2007;2(1):30-34.

97. Ingul CB, Tjonna AE, Stolen TO, Stoylen A, Wisloff U. Impaired cardiac function among obese adolescents: effect of aerobic interval training. Arch Pediatr Adolesc Med. Sep 2010;164(9):852-859.

98. Tsang T, Abhayaratna W, Barnes M, et al. Prediction of cardiovascular outcomes with left atrial size: is volume superior to area or diameter? J Am Coll Cardiol. Mar 2006;47(5):1018-1023.

99. Tsang TS, Petty GW, Barnes ME, et al. The prevalence of atrial fibrillation in incident stroke cases and matched population controls in Rochester, Minnesota: changes over three decades. J Am Coll Cardiol. Jul 2, 2003;42(1):93-100.

100. Benjamin E, D’Agostino R, Belanger A, Wolf P, Levy D. Left atrial size and the risk of stroke and death. The Framingham Heart Study. Circulation. Aug 1995;92(4):835-841.

101. Hirschler V, Acebo H, Fernandez G, de Luján Calcagno M, Gonzalez C, Jadzinsky M. Influence of obesity and insulin resistance on left atrial size in children. Pediatr Diabetes. Feb 2006;7(1):39-44.

102. Kosar F, Aksoy Y, Ari F, Keskin L, Sahin I. P-wave duration and dispersion in obese subjects. Ann Noninvasive Electrocardiol. Jan 2008;13(1):3-7.

103. Gulel O, Yuksel S, Soylu K, et al. Evaluation of left atrial functions by color tissue Doppler imaging in adults with body mass indexes $\geq 30 \mathrm{~kg} / \mathrm{m}(2)$ versus those $<30 \mathrm{~kg} / \mathrm{m}$ (2). Int J Cardiovasc Imaging Apr 2009;25(4):371-377.

104. Di Salvo G, Pacileo G, Del Giudice E, et al. Atrial myocardial deformation properties in obese nonhypertensive children. J Am Soc Echocardiogr. Feb 2008;21(2):151-156.

105. Di Salvo G, Pacileo G, Del Giudice E, et al. Abnormal myocardial deformation properties in obese, non-hypertensive children: an ambulatory blood pressure monitoring, standard echocardiographic, and strain rate imaging study. Eur Heart J. Nov 2006;27(22):2689-2695.

106. Tumuklu M, Etikan I, Kisacik B, Kayikcioglu M. Effect of obesity on left ventricular structure and myocardial systolic function: assessment by tissue Doppler imaging and strain/strain rate imaging. Echocardiography. Sep 2007;24(8):802-809.

107. Sürücü H, Tatli E, Okudan S, Degirmenci A. Evaluation of the effects of obesity on heart functions using standard echocardiography and pulsed wave tissue Doppler imaging. South Med J. Feb 2008;101(2):152-157.

108. Orhan AL, Uslu N, Dayi SU, et al. Effects of isolated obesity on left and right ventricular function: a tissue Doppler and strain rate imaging study. Echocardiography. Mar 2010;27(3):236-243.
Vascular Health and Risk Management

\section{Publish your work in this journal}

Vascular Health and Risk Management is an international, peerreviewed journal of therapeutics and risk management, focusing on concise rapid reporting of clinical studies on the processes involved in the maintenance of vascular health; the monitoring, prevention and treatment of vascular disease and its sequelae; and the involvement of

\section{Dovepress}

metabolic disorders, particularly diabetes. This journal is indexed on PubMed Central and MedLine. The manuscript management system is completely online and includes a very quick and fair peer-review system, which is all easy to use. Visit http://www.dovepress.com/ testimonials.php to read real quotes from published authors. 